\title{
研修ノート
}

\author{
深頸部感染症の診断と治療 \\ 一救急対応の重要性一 \\ Deep Neck Infection \\ -Emergency in Otorhinolaryngology-
}

長谷川 誠・大畑敦

はじめに

深頸部感染症 (deep neck infection) は, 気管・気管支 異物, 急性喉頭蓋炎, 声門下浮腫などと共に, 耳鼻咽喉 科領域に拈ける呼吸困難を伴ら重要な救急疾患のひとつ である. そして抗生剤の発達した現在でも，急激な経過 で死に至る可能性を持つ疾患でもある。したがって正確 な診断に基づいた，適切にして迅速な治療の開始が大変 重要となる.

深頸部感染症は頸部膿瘍の形で発現する．この膿瘍が 頸部の間隙を経て綎隔に達すると, 致命率は極めて高く なる。

深頸部感染症に招いては, 膿瘍を速やかに開放して, 感染が緃隔に至るのを防ぐことが治療の基本である，不 幸にして，膿瘍が縱隔に達している場合でも，ドレーン により体外への排膿を図る。

本稿に打いては, 杏林大学付属病院耳鼻咽喉科拈い て経験した症例に基づいて, 深頸部感染症の原因, 診断 法, 治療について述べる.

\section{原 因}

深頸部感染症は, 主として耳下腺, 顎下腺, 歯牙, 扁 桃, 扣よび乳様突起などが主な感染巣となり，それらの 炎症が波及して生ずると考光られている。

杏林大学付属病院耳鼻咽喉科比いて, 平成 4 年 11 月 から平成 8 年 7 月までに経験した 31 症例では, 口蓋扁桃 がその約 $2 / 3$ の 20 例を占め, 続いてら歯 4 例, 顎下腺唾 石 3 例, 下咽頭梨状窩瘦 1 例, 不明 3 例が認められた.

下咽頭梨状窩瘦は浪かの原因とはやや異なり, branchial anormalyによって生ずるものと考穴られて扣り， 扁桃周囲, 口腔底に感染巣や膿瘍を認めず, 甲状腺上極 付近を中心として膿瘍の形成が認められるものである.

\section{原 因 菌}

我々の経験した症例においては, 溶血性連鎖球菌が最 も多く検出されている. 次いで嫌気性菌の検出率が高か ったが, 検体採取の条件や培地により嫌気性菌の検出率 は変わってくるため, 実際にはその検出率はさらに高か った可能性がある.ナイセリアや黄色ブドウ球菌も高頻 度に検出されている。

ただし，注意しなければならない点は，これらの菌が 原因菌として必ずしも断定できないことである. 頸部膿 瘍で来院する患者のほとんどは, 他院にて大量の抗生剤 をすでに投与されて扣り，なかには細菌培養を試みても， 菌が検出されないケースも見られる。したがって，現実 的には, 培養によって得られた菌種とその抗生剂に対す る感受性を参考にして使用すべき抗生剂を決めることに なる。

\section{症状}

深頸部感染症の一般的な症状としては, 有痛性の頸部 腫脹, 発熱, 時に頸部リンパ節腫脹および開口障害があ る. 深頸部感染症の原因の多くは口腔内に存在するため, 中咽頭, 歯周囲, 口腔底に粘膜の腫脹や排膿を認めるこ とが多い。

特に, 扁桃周囲膿瘍から頸部膿瘍へと進展するケース が多く，咽頭所見が重要である.

咽頭から喉頭粘膜にかけての炎症性浮腫により, 嚥下 困難や䐵下痛, 時には呼吸困難を伴ら。しかしながら， 下咽頭梨状窩瘦の場合には前述したように，他の頸部膿 瘍とは異なった所見を示す.

\section{診断}

血液検查により白血球増多, CRP 值の六進が著明に 認められる. 頸部膿瘍の確定診断には CT が有用である. MRI そよっても診断が可能であるが, 膿瘍の位置や広 


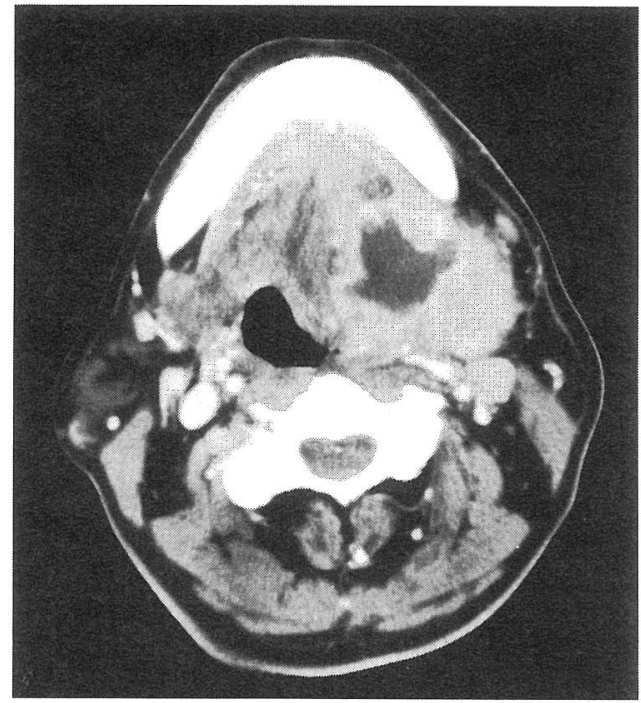

図 1 顎下腺唾石が原因と思われる口腔底の膿瘍 (CT)

がりを知るための解剖学的位置関係の理解には, 骨組織 の陰影が大変役に立つので， CT がもっぱら用いられて いる(図 1 ).

頸部膿瘍の診断のために, 膿瘍の穿刺, 吸引がしばし ば行われる。これは膿瘍の確認とその細菌検査のためで あるが，膿瘍の位置によっては頸部の動静脈潾接して いることもあり, 穿刺によって内出血が起こり, 呼吸困 難の発生につながる可能性もある. 穿刺に際しては慎重 を要する。

頸部膿瘍の診断に際しては, 常に緃隔への波及がある かどらかについてチェックする必要がある。したがって， 胸部エックス線検查は必須である。絶隔への波及が強く 疑われる時には, 胸部 CT 検查が必要となる.

\section{治 療}

1) 治療方針

深頸部感染症の治療の基本は，頸部膿瘍が認められる 場合には，それを直ちに切開排膿することである。

ただし，われわれは膿瘍が舌骨より上方にあり，呼吸 困難もなく糖尿病も合併していないような症例の場合に は, 大量の抗生剤の点滴により, 保存的に 1 日経過を見 ることにしている。しかしながら，保存的治療により 1 日経過を見ても改善が認められない場合には, 迷わず手 術的に切開, 排膿を行っている.

2 ）抗生剂の選択

頸部膿瘍の菌の培養を行うと, 我々の経験例によれば, 溶血性連鎖球菌, 嫌気性菌, 黄色ブドウ球菌, ナイセリ アなどが多く検出される。しかしながら，培養の結果が
分かるのは数日後になるので，初診時にとりあ⿱す尢投与 する抗生剤を決めなければならない。

我々はペニシリン系抗生剤( $\mathrm{PIPC}$ 他)第一選択とし， 時にセフェム系(CEZ，カルパペネム他)を用いている. さらにクリンダマインン (CLDM) を併用することもあ る。我々の症例では，31例中 2 例に MRSAを認めたの で,アルベカシン $(\mathrm{ABK})$, バンュマイシン $(\mathrm{VCM})$ も使 用した.

いずれにせよ，幅広い抗菌力を持つ抗生剤を第一選択 として使用することが大切である。

\section{2 ) 外科的処置}

頸部膿瘍の汪とんぞは, 口腔底，側頸部に生ずるので， 下顎骨枝より 2 横指下方に，下顎骨枝に沿って皮膚切開 を置くか，さらに綐切開を加えた $\mathrm{T}$ 字切開とする.膿瘍 がかなり正中に寄っていても，この皮膚切開で開放可能 である。両側頸部膿瘍の場合には，反対側にも同様の切 開を加光る。

一般に膿瘍に到るには，顎下腺の下から裏側へ用指的 に剥離して，鈍的に膿瘍へ到る（図 2 )。 そして，用指的 に口腔底, 副咽頭間隙を開放する。これが頸部膿瘍開放 の基本手技である。膿瘍が頸部下方へ進展している時に は, 血管鞘, あるいは下咽頭, 食道側面〜後面に沿って 用指的に開放し膿瘍に到る. 縦隔膿瘍の場合にも基本的 には，このルートで排膿を図るが，その時の胸腔内所見 により他の排膿ルートも加える.

排膿には一般にペンローズドレーンを用い，その一端 を皮膚創に縫合し、ドレーンを介して毎日洗浄する。洗 浄には薄めたイソジン液を用いることが多い。

気管切開は，なるべく行って特いた方が無難である. 我々の症例では32例中 25 例に行っているが，あとからふ り返って見ると，必ずしる必要であったとは思われない ケースもある。しかしながら，緊急時のリスクを考光る と, 気管切開は行って执いた方が安全で，必ずしも大げ さとは言光ない。

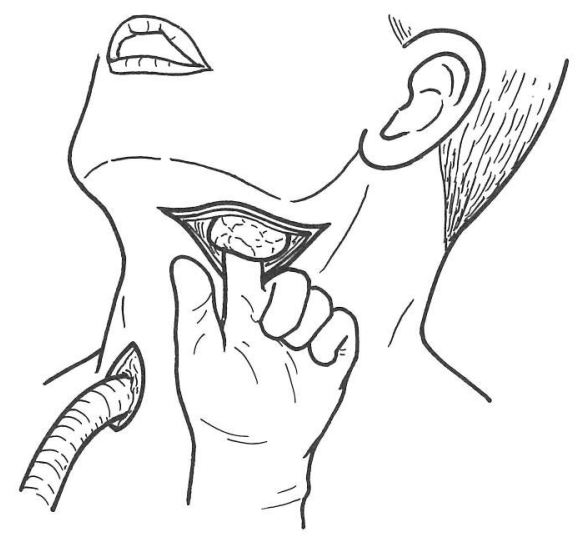

図 2 膿瘍への用指的アプローチ 